\title{
American Indian Identity and Blood Quantum in the 21st Century: A Critical Review
}

\author{
Ryan W. Schmidt \\ Department of Anthropology, University of Montana, Missoula 32 Campus Dr., Missoula, MT 59812, USA \\ Correspondence should be addressed to Ryan W. Schmidt, ryan2.schmidt@umontana.edu
}

Received 8 November 2011; Accepted 29 December 2011

Academic Editor: Santos Alonso

Copyright () 2011 Ryan W. Schmidt. This is an open access article distributed under the Creative Commons Attribution License, which permits unrestricted use, distribution, and reproduction in any medium, provided the original work is properly cited.

Identity in American Indian communities has continually been a subject of contentious debate among legal scholars, federal policy-makers, anthropologists, historians, and even within Native American society itself. As American Indians have a unique relationship with the United States, their identity has continually been redefined and reconstructed over the last century and a half. This has placed a substantial burden on definitions for legal purposes and tribal affiliation and on American Indians trying to self-identify within multiple cultural contexts. Is there an appropriate means to recognize and define just who is an American Indian? One approach has been to define identity through the use of blood quantum, a metaphorical construction for tracing individual and group ancestry. This paper will review the utility of blood quantum by examining the cultural, social, biological, and legal implications inherent in using such group membership and, further, how American Indian identity is being affected.

\section{Introduction}

Identity in American Indian communities and the ability to define tribal membership has continually been a subject of contentious debate. To obtain federal recognition and protection, American Indians, unlike any other American ethnic group, must constantly prove their identity, which in turn, forces them to adopt whatever Indian histories or identities are needed to convince themselves and others of their Indian identity, and thus their unique cultural heritage. Is there an appropriate means to recognize and define just what and who is an Indian? Should it be necessary for federal officials and tribes to continually reconstruct definitions to suit the present sociopolitical climate for American Indian identity? These questions need to be answered in light of American Indian identity politics, including how race serves as a basis for the exclusion or inclusion of "mixed bloods" within tribal communities and the United States society as a whole. In this context, identity has become one of the great issues of contestation in an increasingly multicultural and "multiracial" society.

One approach to answer these complex questions since initial contact between Native American tribes and European Americans has been to define identity through the use of blood quantum, a metaphorical, and increasingly physiological construction for tracing individual and group ancestry. Initially used by the federal government to classify "Indianness" during the late 1800s in the United States, many American Indian tribes have adopted the use of blood quantum to define membership in the group. This paper will explore the utility of blood quantum by examining the cultural, biological, political, and legal implications inherent through such a restricted use of group membership. In addition, blood quantum (and other genetic methods) as a way of tracing descent will be critiqued in favor of adopting a cultural-specific approach that allows inclusive membership and criteria not based upon one's genetic and biophysical makeup. By reducing the reliance on blood quantum to define membership, American Indians can start moving away from an imposed racial past which was artificially created in the first place.

\section{Historical Background}

2.1. Kinship, Blood Quantum, and Scientific Racism. Prior to the arrival of Europeans in North America, ethnographic evidence suggests American Indians established kinship through various systems of lineal descent. Like most human societies, kinship criteria (consanguinity and affinity) varied among groups of Native Americans, having no pan-Indian 
system of tracing descent. Many groups also had systems of naturalization that could confer group membership on nonkin [1]. According to Meyer [2], the term "blood" was more akin to family lineage than modern-day physiological definitions of the term. Churchill [3] elaborates on the internalization of colonial policies in defining Indian identity and the use of blood quantum. He asserts that American Indians have maintained throughout history higher degrees of sociocultural inclusiveness and interaction (i.e., breeding and intermarriage) with other tribes then do non-Indian peoples (Europeans, Africans). Admixed individuals were apparently accepted into Native society with few reservations, though this is most likely a broad generalization not applicable to all groups inhabiting native North America.

The arrival of Europeans brought changes to group identity. Concerns of Indian identity and how it has been commodified and expropriated through continuing colonial practice have been raised [1]. Europeans not only expropriated land and resources, but also Indian identity. Over the next few centuries, the issue of identity shifted from indigenous social-cultural-territorial-based definitions to legal and frequently race-based definitions arbitrarily articulated in congressional laws, administrative regulations, or court cases. In other words, American Indian identity was commodified through bureaucratic procedure [4].

The terms identity, ethnicity, and heritage in American Indian society are all entangled with the English conception of race, borne out of the colonial past with ideological components of exclusiveness and discreteness of group membership. English colonization biophysically defined and manufactured indigenous groups into a synthetic process that formalized and institutionalized differences among early indigenous populations [5]. Based on English standards of civilization and Christianity, early contacts with indigenous groups in North America were explained through a rank system of classification and behavior. Of course, native behavior and appearance were defined by the innateness of racial difference and thus peoples in the New World became the "new savages" to whom the English justified harsh, brutal conditions, and subsequent conquest of native lands.

Race, as it was defined by the English, clearly was perceived as differences in physical appearance (phenotypic variation) and had natural divisions within the human species. From this, arbitrary social meaning was applied to biophysical reality, and as such, was a reality created in the human mind with no actual connection to objective truth. Although fabricated as an existential reality out of a combination of recognizable physical differences, race came about through some incontrovertible social facts: the conquest of indigenous peoples, their domination and exploitation, and the importation of a controllable population from Africa to serve capitalistic needs of the dominant European society [5].

Early scientific analysis sought to explain and perpetuate the race concept by applying technological and methodological rigor to the study of innate biological differences among human groups. Swedish botanist Carolus Linnaeus (1707-1778), considered the founder of scientific taxonomy, established a classificatory system still in use today that denotes all living forms by "genus" and "species." This taxo- nomic system was also applied to the human species [6], under the false assumption that humans could be divided into subgroups, such as a subspecies. Group differences and subsequent descriptions indiscriminately mixed physical features with supposed traits for character, disposition, and behavior (all features seen today as external and cultural). Broken up into four "species," Linnaeus defined predominate geographical human groups (Americanus, Asiaticus, Africanus, and Europeaus) using innate terminology not only for physical characteristics but also qualities of behavior and temperament ascribed to fixed entities.

Perhaps unintentional, but the implications went far beyond immediate taxonomic concerns. First, this scientific classification system was given an aura of permanence and rigidity to conceptions of human differences. Second, the categories accept, without question, the linkage of physical characteristics with behavioral ones, thus strengthening a component of the racial worldview set in place at the time. Third, in accordance with social, economic, and political realities at this time, these classifications lent themselves to hierarchical structuring, fostering an impression of inequality and placing Europeans in the position of having the most progressive and positive cultural features, as opposed to negative characteristics associated with the so-called "savages," that is, Americanus and Africanus. Lastly, scientists studying the natural order of humankind legitimized the inferior qualities ascribed to non-Europeans and justified their lower position in world societies. Thus, scientific sanction and scholarly credibility were commodified in the public's mind for prevailing images and stereotypes of nonEuropean groups $[1,5]$.

Unfortunately, the prevailing scientific paradigm and misconceptions about human variability were also accepted by some of the leading, and founding, biological anthropologists of North America [7]. The foundation of modern physical anthropology in the United States was strongly influenced by the European tradition of anatomy and physiology. Those most influential among these thinkers were German naturalist and anatomist Johann Friedrich Blumenbach (1752-1840) and American-born physician Samuel George Morton (1799-1851). Blumenbach has been called the "father of physical anthropology" and also the "founder of racial classifications" [7]. He coined some of the racial jargon and typology still much in use today, such as the word Caucasian, which was derived from the mountain range between modern states of Russia and Georgia.

The typological tactic for measuring the human skull progressed through the works of Albert Hooton (1887-1954) of Harvard University and Aleš Hrdlička (1869-1943) of the Smithsonian Institution. Even though Hrdlicka had very little training in anthropology, he went on to pioneer the field of physical anthropology with countless publications and founding the flagship journal American Journal of Physical Anthropology (1918) and also contributed to the founding of the American Association of Physical Anthropologists in 1928. The use of new quantitative methods and paleopathological terminology have opened the doors to new avenues of research in the present, but at the time both Hooton and Hrdlicka supported (perhaps implicitly) the typological 
paradigm, changing a little in the way anthropologists studied human variation and viewed or classified races.

Beaulieu [8] describes a case study involving Hrdlička in the context of the role and function of scholars in the development and implementation of federal Indian policy, and more specifically, the social sciences relationship to American Indian societies. The study centered on the White Earth Reservation in Minnesota and land allotment policy in the early 20th century. In Beaulieu's words, "two anthropologists came to White Earth Reservation to measure, scratch the skin, pull the hair and otherwise physically examine the Chippewa people living there to determine who was a mixed-blood Indian and who was (a) full-blood Indian [8, page 282]." At this time, many full-blood American Indians were not allowed to sell their allotment land, being deemed legally incompetent by the government of the United States. The appeal to science to aid in determining mixed and full blood for the purposes of land allotment was essential to the United States attorney who sought to bring charges against a number of entrepreneurs, lumber companies, and banks who had illegally obtained allotments from those "full blood" individuals ineligible to sell. Albert Jenks, professor of anthropology at the University of Minnesota, and Aleš Hrdlička were contracted by the Justice Department in 1914 in an effort to distinguish mixed from full-blooded Chippewa [9].

Using what today would be called pseudoscience to support a racial ideology established through "scientific objectivity," the physical anthropologists made claims of being able to accurately detect and separate mixed bloods from full bloods on the basis of quantitative hair characteristics, that is, curly hair from straight hair. This assumption, inherently flawed, was made on the basis of having no contact with the Chippewa themselves. Instead, Hrdlička and Jenks based their theory on standards from an earlier analysis examining hair among indigenous peoples (the Pima) in the southwestern United States. In fact, upon further investigation using hair measurements, Jenks found that

\begin{abstract}
"Both Hrdlicka and myself have hair of the most typical negro [sic] type and the Scandinavians have hair more circular in cross-section than our pure blood Pima Indians. I am not sure yet what these facts mean; but either the old classification of human races by hair texture is not of scientific value or Dr. Hrdlicka and I are related to the negro and the Scandinavians are simply bleached out Mongolians [8]."
\end{abstract}

As seen in this study, the use of science fit in with preconceived ideas of the racial division and natural separation of the human species. Since the nineteenth century, physical anthropology was really one of measuring Indian skulls (as the majority of the body of data derived); Jenks and Hrdlička were in a privileged position to determine the status and identity of American Indian people. They employed scientific theory combined with enhanced technological capability and thus were able to validate and perpetuate the prevailing paradigm of the time.
Although the explanations of physical anthropologists in the mid 20th century shifted from the pursuit of racial classification to biological diversity and adaptation, Brace [10] noted that many studies focused on the testable aspects of human biology, but in the end, they generally conclude with a named list of human "races" assigned to various geographic and local regions. The connection between biology discussed and the races named at the end is never clearly spelled out, and in fact the attentive reader cannot discover, from the information presented, just how the racial classification was constructed-other than the fact that this just seems to be the way anthropologists have always done things.

During the 1960s and 1970s, many anthropologists began to adopt the term "cline" in the place of race [11]. Advocating the study of individual traits and the selective pressures modifying these traits, many anthropologists began abandoning racial classificatory systems and discarding the scientific validity of the race concept. Among biological anthropologists that study human variation today, it is a wellknown observation that the majority of human diversity is within populations, rather than among them [12], indicating that race, as a fixed typological construct, fails to hold water. Given the paucity of this data, why would groups today still hold on to such rigid, discrete divisions, and seemingly outdated observations describing human variation and diversity? To answer this question in the context of American Indian history and practice, we must understand how the use of blood quantum was developed and implemented in its relationship with the federal government of the United States.

\section{Blood Quantum and American Federal Indian Policy in Historical and Legal Context}

3.1. The Treaty Period (1817-1871). How did American Indian groups, being subjected to racist thought and exploitation in 19th century North America, come to adopt the principle of blood quantum, clearly a racist ideology sprung from the ashes of colonial policy? This question has been taken up by countless legal scholars and historians [1319]. Of primary interest here is the definition and use of blood quantum throughout history as used both by federal governmental agencies and tribes. This section is divided up into three sections for heuristic purposes: the treaty period (1817-1871), the reservation period (1871-1887), and the allotment period (1887-1934).

The use of "blood" to trace ancestry has historical roots, mainly applied to persons of "mixed" blood. Meyer [2] explores the etymological roots of the term "blood" and notes that its use extends deep into Anglo-Saxon tribal psychology. By 1200, the term blood became increasingly synonymous with lineage, descent, and ancestry in association with royal claims to property and power and "presages modern conceptions of "race."” Meyer [2] claims that native conceptions of blood were more subtle and nuanced and did not necessarily connote physiological meaning. However, as American Indian and European relations progressed, native 
peoples began to adopt the strictly physiological meaning of blood, deemphasizing the metaphorical extension of kinship and lineage. In the context of people with admixed blood, Meyer [2] observes

"White blood" might uplift darker "blood", but
not as quickly as "tainted blood" polluted. And the
stain of degeneracy attached to all those of mixed
descent for those of the dominant order. It was a
contest that might be won only through phenotype
and cultural behavior. Color lines drawn in the
racial caste system remained impermeable unless
an individual looked lighter and associated with
and behaved like those of "purer blood."”

The earliest use of "blood" to trace genealogy occurred in precolonial governments of North America [20]. For example, Virginia in 1705 came to a legal definition of "mixed blood" by coining the term "mulatto" for those individuals with at least $1 / 8$ blood African ancestry or $1 / 2$ Indian ancestry. "Colored" and "mulatto" were defined by a number of states in colonial times, usually for the purposes of restricting and/or limiting civil and/or property rights.

After the United States was officially established as a nation-state with constitutional authority, treaties became an essential component in negotiating with tribes as sovereign political entities. Treaties were negotiated for various purposes, including ceding tribal land, and were the primary documents that defined the legal relationship between the United States and tribes until the abolition of treaty-making in 1871 [18]. The language of blood as adopted in state governments during colonial times continued to be used at the federal level in treaty negotiations, usually for the purpose of describing people of mixed American Indian and non-Indian ancestry. One of the earliest references to treaties with language of "half-bloods," "half-breeds," or "quarter bloods" began in 1817 to grant various benefits, usually land and money, to mixed individuals. Although the use of blood quantum defined certain treaty rights to specific individuals, the definitions were not extended to tribal membership. The language of blood, however, was entrenched in the minds of federal officials when the United States began to expand West and interact with more tribal nations, but identity and blood were not codified by any means and its use more generally was situational specific.

Although federal officials were aware of the use of blood quantum to trace ancestry, it was infrequently employed. Spruhan [18] contends officials prior to the early twentieth century preferred to define tribal membership through matrilineal and patrilineal descent, or those criteria set up by the specific tribe. He concludes that blood quantum only became important as a method to defining tribal membership in the early twentieth century when it was firmly rooted in federal Indian policy as seen in the changing perception of the government's relationship to Indian tribes. According to Spruhan [14], "inconsistency is the main theme in federal applications of blood quantum," caused by the lack of clear guidance by Congress, the branch of government with primary authority over Indian affairs under the United States Constitution. Without any clear guidance and operational definitions, Congress failed to define American Indian status throughout the Treaty Period, and then only did so in the context of the distribution of American Indian property and the allotment of American Indian lands.

This period did include references to blood quantum; however, blood quantum varied from treaty to treaty, and defined entitlement to specific properties or lands, not membership in those tribes or Indian status for all purposes. The federal government, in treaty negotiation, had to decide if "mixed-bloods" constituted a separate tribe for land cessions and whether they were subject to restrictions imposed by the government as "guardians" of Indians (see court ruling Cherokee Nation v Georgia, 1831 [21]). It was decided that there were two separate theoretical solutions: a mixed-blood was a citizen of the United States under virtue of his or her white ancestry and therefore not an Indian; however, the mixed-blood was also an Indian if he or she was a tribal member.

3.2. The Reservation Period (1871-1887). In 1871, Congress abolished treaty-making with tribes, declaring no tribe in the future would be considered an "independent nation, tribe, or power with whom the United States may contract by treaty" $[4,18]$. Tribal recognition, that is, formal diplomatic acknowledgement of a tribe's legal status as a sovereign, began to be used in a jurisdictional sense opposed to previous implications simply meaning tribes existed. Over time, the Supreme Court has given Congress "plenary power" over Indian affairs, which means Congress has primary authority over Indian affairs among the branches of federal government and may control or regulate the powers of tribes, including dissolving tribes as political entities (see Santa Clara Pueblo v Martinez, 1978 [22] and Cotton Petroleum Corp. v New Mexico, 1989 [23]).

During the reservation period, legislative and federal regulation, carried out by the Bureau of Indian Affairs, encouraged assimilation of individual Indians into American society. As the bureaucracy increased, so did questions concerning the "blood" status of American Indians for federal benefits or federal jurisdiction. These questions turned into extensive judicial and legislative attempts to define Indian identity and individuals with mixed ancestry. Most notably was the patrem rule (patrilineal descent) that stated all those with a non-Indian paternal ancestor were non-Indian, no matter the amount of "Indian" blood. This concept was never codified and sanctioned by the Supreme Court, although they did rule in Elk $v$ Wilkins [24] that tribal allegiance be given primacy in the determination of citizenship in the tribe, thus not entirely excluding mixedbloods from the legal status of Indian [18].

3.3. The Allotment Period (1887-1934). The allotment era (1887-1934) saw the concept of blood quantum become officially integrated into the legal status of Indian identity for the purposes of dividing communal tribal lands into 
individual parcels called allotments. The General Allotment Act (also known as the Dawes Act), passed in 1887, was an attempt by the federal government for a definitive assimilation policy to firmly disband tribal entities by encouraging individual family farming, and thus ridding their responsibilities to tribal members as "guardians" and "protectors." The allotment policy was, in the words of President Theodore Roosevelt, "a mighty pulverizing engine to break up the tribal mass [4, page 117]." By 1934, 118 out of 213 reservations had been allotted, resulting in the loss of nearly 90 million acres of tribal lands [4]. Jaimes [14, page 126] notes that the use of blood quantum in allocating Indian land was in accordance with the "superior" notion of European individual property ownership opposed to collective ownership. She also notes how many Indians did not meet the genetic qualifications of $1 / 4$ or more blood, thereby legally reducing native land and manipulating the process by parceling out the best land to individuals "competent" enough to receive pristine real estate, which would then be bought up by future homesteaders and corporations.

The history of the allotment period and determination of Indian status through the practice of blood quantum is fraught with difficulties in definition and inconsistencies and contradictions in the historical application of these policies. Mixed-bloods were a defining contradiction in the executive branch, as many mixed-bloods were denied allotments for being US citizens (see Black Tomahawk $v$ Waldron, 1891); however, officials were still accepting mixed-blood signatures in land cession agreements as Indians. Put most succinctly by Spruhan [18], "The executive branch had embraced mixedbloods for the purposes of ceding land, but now denied them allotments once it divided the remainder."

The courts continued to rule on cases of mixed-blood allotment claims until reaching the Supreme Court in Halbert $v$ United States [25], which held that tribes had the right to define eligibility based on tribal membership and not any specific degree of blood. During this time, those who were considered "full blood" as tribal members were not allowed to sell land, as it was claimed at the time that full-blood Indians were not as competent in their abilities to manage business affairs as defined by English law [26]. In Lone Wolf v Hitchcock [27], the courts ruled that Congress had unfettered power over Indians as guardians over their lands. In this sense, Indians were "wards of the government" and Congress could apply "full administrative power" over tribes to dispose of Indian lands.

Wholesale American Indian allottees were released from their restrictions of selling their land, thus opening up millions of acres to European settlers. It is in this period that blood quantum was used more generally to determine "competency" to release Indians from their allotment restrictions. Under a provision of the Dawes commission, official rolls were created for "Indians by blood," intermarried white citizens, and freedman to determine eligibility. From 1903 to 1908, Congress released all Indians, no matter how much "blood" ran through their veins, from allotment restrictions. Thus, blood quantum became an efficient and effective way to identify Indians and determine appropriate legislation concerning land sales, and latter, for educational purposes.

3.4. Tribal Enrollment and the Indian Reorganization Act of 1934. It was during the "allotment period" that official tribal enrollment took form in support of the existing ideology of using blood quantum as a determinant of tribal affiliation $[14,17,28]$. US courts set a precedent in 1905 in the case of Waldron v. United States [29] that upheld tribal authority to determine enrollment policies. Most federally recognized tribes (as implicitly prescribed under the Federal Acknowledgment Act of 1978) require a certain level of blood quantum, ranging from "full" Indian blood to $1 / 32$ Indian blood. The government, through its implicit genetic "reading" of federal recognition, does not force tribes to implement blood quantum criteria; however, the Bureau of Indian Affairs provides a step-by-step process for guiding tribal enrollment, even providing charts on how tribes should determine blood quantum [17].

Tribal enrollment constitutes a significant element in shaping modern American Indian identity, and as such, attention has been given in the literature to its historical developments [3, 14, 17, 28]. Harmon [28] offers dynamic insight into the complexity of the political process for the creation of tribal enrollment by government officials and Indians residing on the Colville Reservation of northeastern Washington, suggesting a degree of agency for those individuals who had a particular stake in the process. This is contrary to the more polemic stance taken by Churchill [3], Jaimes [14], and TallBear [17], who believe the tribes participating in tribal enrollment internalized a racist colonial practice by incorporating blood quantum and were "ubiquitously forced or duped into acceptance of Euro-American racial ideology" [17, page 90]. Harmon [28] believes unless the issue is framed in historically grounded studies, the implication that tribes were "duped" is simply conjecture. Harmon [28] continues (pages 179, 200)

"... the Coleville documents tell a more complex, ambiguous story than [some blood quantum crit$i c s$ and advocates] do. In the enrollment councils, federal agents did not brainwash or impose their will on Indians; neither did Indians resolve to draw an economically strategic, racially defined boundary around themselves. Rather, officials and Indians participated in a prolonged discourse that I would characterize as incomplete mutual education and accommodation... All tribal enrollment efforts obliged the descendants of Native people to think about where they fit in a white-dominated, racialized world... In response, such people had to rethink their relationships, taking into account the momentous consequences of U.S. domination. Whether or not the government accepted their views on a particular individual's status, enrollment gave them occasion to articulate, debate, and revise their definitions of "Indian" and "tribe"." 
Another study emphasizing a degree of American Indian autonomy contra the claims of the government dictating a racial basis for tribal membership is Trosper's 1976 study of the Flathead reservation in western Montana [30]. This author argues that the Confederated Salish and Kootenai Tribes were not coerced into adopting strict blood quantum criteria for group membership; however, the tribes implemented restricted membership criteria in an effort to maintain self-preservation. He suggests that Flathead reservation members eventually had to succumb to a racialization of tribal identity, in which "they had to adopt their conquerors' idea of what an "Indian" is [30, page 258]". Even this statement seems too generalized in light of his findings. The complex nature of the allotment process, determining enrollment, and eventually adopting tribal constitutions explicitly defining group membership need to be understood in its historical and cultural context: Flathead Reservation members chose to adopt a constitution of exclusivity in light of the contentious nature of land sales, natural resource ownership, and general economic benefits conferred upon official members of the tribe.

In 1934, Congress passed the Indian Reorganization Act. The Act, also known as the Howard-Wheeler Act (cosponsored by Senator Wheeler of Montana), encouraged tribes to form their own governments toward a process of self-determination. The authors of this act intended a few purposes, including discontinuing the use of allotments of reservations, providing for the acquisition of lands for landless Indians, permitting tribes to organize into corporations, establishing a system of credit, supplying American Indians with educational and technical training and preferential employment within the Bureau of Indian affairs, and stabilizing tribal governments [4, page 140]. A central feature to this act was the establishment of US sanctioned tribal governments patterned after corporations. The Bureau of Indian Affairs encouraged tribal leaders to codify constitutions based on a US model. In addition, these constitutions explicated enrollment requirements and ruled on individuals' eligibility. Making the situation more perplexing was how the government established eligible criteria for benefits like education and health care. Although governmental requirements ( $1 / 4$ blood quantum among them) did not interfere with tribal membership criteria, it added an additional layer to the already convoluted question of "Who is an Indian"?

According to Hagan [13], the act inaugurated the "Indian New Deal," defining three categories of people: (1) all persons of Indian descent who were members of a recognized tribe under federal jurisdiction; (2) all persons who were descendents of such members who on June 1, 1934, were residing within the present boundaries of an Indian reservation; (3) all other persons of one-half or more Indian blood. This signified the beginnings of "degree of Indian blood" as a means to establish membership in the tribe through the adoption of appropriate constitutions. The HowardWheeler Act encouraged tribes to compile membership rolls. It is these rolls in which a majority of tribes trace lineage and thus trace a blood relationship. Indian identity became more significantly associated with biological conceptions, in which the definition of Indian was further cemented through biology rather than culture. Churchill [3, page 49] states that

"With the embrace of the IRA [Indian Reor-
ganization Act] constitutions ... Euro-American
definitions of and constraints upon Indian identity
were formerly as well as psychologically and intel-
lectually internalized by Native America. From
there on, the government could increasingly rely
upon Indians themselves to enforce its race codes."

\section{Blood Quantum Usage in the Present}

4.1. Demographic Implications. According to some authors $[3,14,31,32]$, the continued use of blood quantum as a way to ascribe membership in a Native American tribe has dire consequences. These authors feel blood-quantum policies are little other than genocidal (or "autogenocide by definitional and statistical extermination" as characterized by Churchill [3, page 51]), which will ultimately end with extinction of the original indigenous people of native North America. Summarizing the process (although slightly generalizing at the same time), Limerick [31, page 338] writes, "Set the blood quantum at one-quarter, hold to it as a rigid definition of Indians, let intermarriage proceed as it had for centuries, and eventually Indians will be defined out of existence. When that happens, the federal government will be freed of its persistent "Indian problem."”

Demographer and anthropologist Thornton [32] is keenly aware of the sentiment expressed by Limerick [31]. Thornton [32] examined 20th century demographic shifts in American Indian society and the population "recovery" with reference to urbanization, intermarriage, and differing definitions on the official census. Thornton [32] observed an increased self-identification of American Indian starting in the 1960s that does not correlate with official tribal enrollment data from federally recognized tribes. People with a mixed ancestry are increasingly self-identifying with being an American Indian, a "desire to affirm a marginal ethnic identity." Hagan [13] expounds on this argument calling these particular individuals "ersatz Indians." This description is applied mainly to those claiming Indian ancestry for the purpose of economic gain or to receive health and education benefits. Modern times has brought increased urbanization and hence increased interaction with nontribal members, thus facilitating marriage between groups.

As a consequence of increased interaction, over 60 percent of all American Indians are married to nonIndians, which has certain implications pertaining to group membership (as established by blood quantum), heritage, and identity. For example, Congress has estimated by the year 2080 less than 8 percent of American Indians will have one-half or more Indian "blood" [33]. This raises several interesting identity questions, one important question being how much "racial admixture" can occur before American Indian people cease to be identified as a distinct people? Individuals enrolled in federally recognized tribes receive a Certificate of Degree of Indian Blood (CDIB) by the Bureau of Indian Affairs, specifying a certain degree of 
Indian blood. Each tribe has its own blood quantum requirements. Some, like the Cherokee of Oklahoma, do not have a minimum quantum [34], while others have more restrictive requirements (1/2 or more). What dangers are posed to American Indian sovereignty and continuity if the tribes and the federal government continue to identify "Native American" on a racial instead of a cultural or more explicitly political basis?

4.2. Exclusivity. The concept of exclusivity is embedded in the racial paradigm borne out of the colonial past. Smedley [5, page 71] remarks how exclusiveness is fundamental to the ideology of race, and it can "only be maintained by the erection of social-cultural boundaries between populations that (1) become broad barriers against interaction between "races", (2) preclude any possibility of egalitarian relationships, and (3) do not recognize or provide for intermediate realities". She goes on to say, "Such boundaries are most effective when they can be transmuted into a biological axiom."

Thornton [32] quantifies this exclusive sense by observing the data of reservation-versus nonreservation-based membership criteria and degree of blood required. The data suggests that tribes located on reservations have maintained a higher blood quantum requirement as a function of geographic isolation. The reservation has tended to isolate the tribe from non-Indians and intermarriage with them. Conversely, tribes with a more inclusive membership have set a lower (or nonexistent) blood quantum since their populations generally have increased interaction and intermarriage with non-Indian populations (Table 1).

Exclusivity can also be extended to a growing facet of American Indian society: gaming. Neath [35] discusses Indian gaming in the context of tribal membership restriction and blood quantum. According to the National Indian Gaming Commission, net revenues from Indian gaming totaled 26.5 billion dollars in 2010. American Indian gaming, as a constant source of tribal revenue, has steadily grown since the Indian Gaming and Regulatory Act (IGRA) was given congressional approval in 1988 [35]. See Figure 1 for the growth of Indian gaming over a ten-year period (20012010). In fact, in 1993 Indian gaming grossed over 5 billion dollars, exceeding the federal budget for Indian assistance by 2 billion dollars.

Gaming provides a means for employment and economic sustainability and self-determination in some of the poorest areas of the United States. Relatively recent figures (1990) estimate that unemployment on reservations has averaged from 50 to 90 percent. The IGRA has allowed tribes to regulate gaming activities on tribal-owned lands and contribute directly to the economic development of reservations in the form of public works projects, for improving health and education, or distribute revenue on a per-capita basis to individual members of the tribe. As semisovereign nations, tribes are exempt from most state and federal taxes, giving them an advantage over private American casinos.

Tribes have the right to set their own membership requirements, which results in a fundamental dilemma: on the one hand, tribes need to control population growth

TABLE 1: Percentages by blood quantum that are reservation based*.

\begin{tabular}{lcc}
\hline Blood quantum & \% Reservation based & $N$ \\
\hline $1 / 2$ or more & 85.7 & 21 \\
$1 / 4$ or less & 83.1 & 183 \\
No min. req. & 63.9 & 98 \\
\hline
\end{tabular}

*From Meyer [2].

Growth in gaming revenues ( $\$$ in billions)

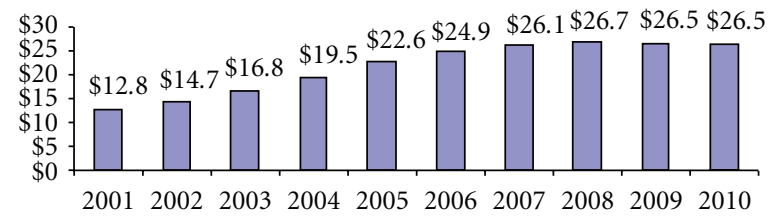

Figure 1: Indian Gaming Revenue (2001-2010). Source: National Indian Gaming Commission (2011).

to apportion the benefits of gaming to deserving tribal members and sustain reservation economic development, which blood quantum offers a simple and efficient solution; however, through an increasingly narrow, exclusive conception of tribal identity, they face two equally bleak prospects: (1) a shrinking population and decreased political base, and/or (2) stricter federal court or congressional scrutiny of tribal laws. Congressional oversight of tribes will eventually lead to an inevitable fact if blood quantum requirements are allowed to run their course: termination. In the 1950s and 1960s, certain tribes that were deemed too small were "terminated" by the federal government, losing a recognized status and subsequent benefits. Essentially, termination means the death of a tribe as a political entity.

The economic incentives of Indian gaming have given some tribes the challenging (and controversial) decision for adopting race-based, exclusive membership criteria. Neath [35, page 705] believes that gaming success, unlike other developments on reservation land (such as exploiting natural resources), offers tribes a unique chance to "reject foreign conceptions of tribal identity and return to a definition of themselves they once held: an inclusive definition whereby shared culture defines tribal membership." However, culturebased standards will only prove effective if they can supplant the more feasible (and simple) means of blood quantum. Blood quantum offers a simple and inexpensive way of determining and limiting tribal identity. Is there an easier and more effective way to evaluate identity?

\section{Blood Quantum's Contemporary: Genetic Testing}

Can an individual's ethnicity be identified by the genetics of his biology? This question is often investigated through the use of genetic testing that allows individuals to see "where they came from" [16]. A brief Google search on the Internet reveals a number of websites and companies that offer genetic testing that will reveal one's ancestry and by definition, one's 
ethnicity. But ethnicities are fluid cultural constructions that can change multiple times, not something easily identifiable in our genes. This issue has been studied in a legal context by Beckenhauer [16], who discusses contemporary methods of ancestral determinations (through DNA markers) and asks if such an approach is an improvement over the simplistic assumptions of blood quantum. Ultimately, genetic means are still rooted in a biologically determined significance, and not in kinship patterns that are culturally identifiable.

Biological anthropologists and geneticists have been fascinated by American Indian biology and as such have put forth probing literature into Native American origins, colonization, variation, and identity [36-39]. The majority of these studies use either mitochondrial DNA (mtDNA) or Y-chromosome DNA as the unit of analysis due to uniparental inheritance (maternal for mtDNA and paternal for Y-chromosome). That is, lineages can easily be traced through the mother or father using either of these two methodologies because of the non-recombining nature of their genetic makeup. Unique haplogroups are specific to populations, such as may be found among Native American groups. For example, American Indian mtDNA haplogroup typing has revealed a few "major" haplogroups [37]. These include haplogroups A, B, C, D, and X (although X has also been linked to European groups). Some researchers believe the identification of these haplogroups should be able to facilitate establishing ancestor/descendent relationships between modern and prehistoric groups of Native Americans [37].

These findings could have significant implications for individuals and tribes alike. TallBear [17] discusses the case of the Western Mohegan tribe, who contracted for genetic testing to "prove" their legal status as a federally recognized tribe in the state of Vermont. The Mohegan tribe had little documentation, supporting ethnographic evidence, and had not signed a treaty, thereby lacking the requisite genealogical information necessary to make a case for tribal recognition. Through genetic testing, members of the tribe were able to genetically relate to an existing tribe, located in Wisconsin. Native American tribes feared this case (and pending legislation) might implement stricter regulatory procedure underlying Indian identity; that is, the requirement of taking a DNA test to prove tribal affiliation. Future legislation, coupled with genetic analyses, coincides with previous attempts to equate culture with biology such that assumptions which continue to be perpetuated in determining a persons' or peoples' political rights and cultural identity are biologically determined.

\section{Conclusion}

Unfortunately, genetics are no panacea for identifying Indian ancestry. Ancestry, although based in our genes through mating practices, migration and evolutionary forces, is also based upon kinship-cultural affiliation that equates "blood" in the purest metaphorical sense. Racial ideology has persisted in genetic methods claiming authenticity in technological rigor. Not unlike the physical anthropologists of the late 19th and early 20th centuries, biological determinism and its modern equivalent genetic essentialism are often difficult to move away from. Race, ethnicity, and even identity are social constructs not easily established in human biology. How American Indian identity is defined, then, should not be based on exclusive criteria. However, tempting it may be to use Euro-American definitions of identity to maintain a cultural uniqueness, blood quantum is not the solution. What is needed, as explained by Beckenhauer [16] is to work toward a functional definition of identity, one of how to reconcile cultural affiliation and self-identification with exclusionary definitions based on biology, a necessity to effectively allocate limited federal funds, thus striking a balance between inclusivity and exclusivity. Identity is not something that can be cordoned off with definable, fixed boundaries. It must be in continual process, one that allows a fluid identity fixed in cultural construction, not something inherently and innately fixed in the human genome, defined by blood or any other facet of biology (real or imagined).

\section{Acknowledgment}

The author would like to thank Gregory Campbell for discussion and implementation of this paper. His remarks greatly clarified numerous issues surrounding American Indian identity and the use of blood quantum in American Indian communities.

\section{References}

[1] G. P. Castile, "The commodification of Indian identity," American Anthropologist, vol. 98, no. 4, pp. 743-749, 1996.

[2] M. L. Meyer, "American Indian blood quantum requirements: blood is thicker than family," in Over the Edge: Remapping the American West, V. J. Matsumoto and B. Allmendinger, Eds., pp. 231-49, University of California Press, Berkeley, Calif, USA, 1999.

[3] W. Churchill, "The crucible of American Indian identity: native tradition versus colonial imposition in postconquest North America," American Indian Culture and Resource Journal, vol. 23, pp. 39-67, 1999.

[4] D. E. Wilkins, American Indian Politics and the American Political System, Rowman \& Littlefield, Oxford, UK, 2nd edition, 2007.

[5] A. Smedley, Race in North America: Origin and Evolution of a Worldview, Westview Press, Boulder, Colo, USA, 3rd edition, 2007.

[6] G. Broberg, "Homo sapiens_Linnaeus's classification of man," in Linnaeus: The Man and His Work, T. Frängsmyr, Ed., pp. 156-194, University of California Press, Berkeley, Calif, USA, 1983.

[7] J. H. Mielke, L. W. Konigsberg, and J. H. Relethford, Human Biological Variation, Oxford University Press, New York, NY, USA, 2010.

[8] D. L. Beaulieu, "Curly hair and big feet: physical Anthropology and the implementation of land allotment on the White Earth Chippewa reservation," The American Indian Quarterly, vol. 8, no. 4, pp. 281-314, 1984.

[9] A. Jenks, "The practical value of Anthropology to our nation," reprinted from Science, vol. 4, p. 4, in Albert E. Jenks papers, University of Minnesota archives, 1916. 
[10] C. L. Brace, "On the race concept," Current Anthropology, vol. 5, pp. 313-320, 1964.

[11] F. B. Livingstone, "On the non-existence of human races," Current Anthropology, vol. 3, pp. 279-281, 1962.

[12] J. H. Relethford, "Craniometric variation among modern human populations," American Journal of Physical Anthropology, vol. 95, no. 1, pp. 53-62, 1994.

[13] W. T. Hagan, "Full blood, mixed blood, generic, and ersatz: the problem of Indian identity," Arizona and the West, vol. 27, pp. 309-326, 1985.

[14] A. M. Jaimes, "Federal Indian identification policy: a usurpation of indigenous sovereignty in North America," in The State of Native America: Genocide, Colonization, and Resistance, A. M. Jaimes, Ed., pp. 123-139, South End Press, Boston, Mass, USA, 1992.

[15] M. Neath, "American Indian gaming enterprises and tribal membership: race, exclusivity, and a perilous future," University of Chicago Law School Roundtable, vol. 2, pp. 689-709, 1995.

[16] E. Beckenhauer, "Redefining race: can genetic testing provide biological proof of indian ethnicity?" Stanford Law Review, vol. 56, no. 1, pp. 161-190, 2003.

[17] K. Tallbear, "DNA, blood, and racializing the tribe," Wicazo Sa Review, vol. 18, no. 1, pp. 81-107, 2003.

[18] P. Spruhan, "A legal history of blood quantum in federal Indian law to 1935," South Dakota Law Review, vol. 51, pp. $1-50,2006$.

[19] K. Gover, "Genealogy as continuity: explaining the growing tribal preference for descent rules in membership governance in the United States," American Indian Law Review, vol. 33, no. 1, pp. 243-309, 2008.

[20] J. D. Forbes, Africans and Native Americans: The Language of Race and the Evolution of Red-Black Peoples, University of Illinois Press, Urbana, Ill, USA, 1993.

[21] Cherokee Nation v. Georgia, 30 U.S. 1, 1831.

[22] Santa Clara Pueblo v. Martinez, 436 U.S. 49, 1978.

[23] Cotton Petroleum Corp. v. New Mexico, 490 U.S. 163, 1989.

[24] Elk v. Wilkins, 112 U.S. 94, 99, 1884.

[25] Halbert v. United States, 283 U.S. 753, 1931.

[26] T. Biolsi, "The birth of the reservation: making the modern individual among the Lakota," American Ethnologist, vol. 22, pp. 28-54, 1995.

[27] Lone Wolf v. Hitchcock, 187 U.S. 553, 1903.

[28] A. Harmon, "Tribal enrollment councils: lessons on law and Indian identity," Western Historical Quarterly, vol. 32, pp. 175200, 2001.

[29] Waldron v. United States et al., 413, 1905.

[30] R. L. Trosper, "Native American boundary maintenance: the Flathead Indian reservation, Montana, 1860\&1970," Ethnicity, vol. 3, pp. 256-274, 1976.

[31] P. N. Limerick, The Legacy of Conquest: The Unbroken Past of the American West, W.W. Norton \& Company, New York, NY, USA, 1987.

[32] R. Thornton, "Tribal membership requirements and the demography of "old" and "new" Native Americans," Population Research and Policy Review, vol. 16, no. 1-2, pp. 33-42, 1997.

[33] F. M. Bordewich, "Revolution in Indian country," American Heritage, vol. 47, no. 4, pp. 34-46, 1996.

[34] C. Sturm, Blood Politics: Race, Culture, and Identity in the Cherokee Nation of Oklahoma, University of California Press, Berkeley, Calif, USA, 2002.
[35] M. Neath, "American Indian gaming enterprises and tribal membership: race, exclusivity, and a perilous future," University of Chicago Law School Roundtable, vol. 2, pp. 689-709, 1995.

[36] J. H. Moore and J. E. Campbell, "Blood quantum and ethnic intermarriage in the Boas data set," Human Biology, vol. 67, no. 3, pp. 499-516, 1995.

[37] M. H. Crawford, The Origins of Native Americans: Evidence from Anthropological Genetics, Cambridge University Press, Cambridge, UK, 1998.

[38] R. L. Jantz and D. W. Owsley, "Variation among early North American crania," American Journal of Physical Anthropology, vol. 114, pp. 146-155, 2001.

[39] S. I. Perez, V. Bernal, P. N. Gonzalez, M. Sardi, and G. G. Politis, "Discrepancy between cranial and DNA data of early Americans: implications for American peopling," PLOS ONE, vol. 4, no. 5, Article ID e5746, 2009. 


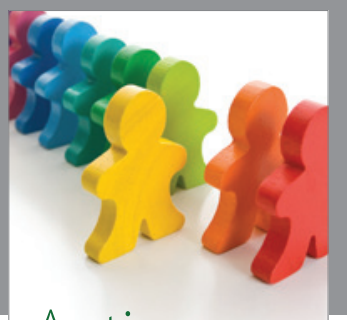

Autism

Research and Treatment
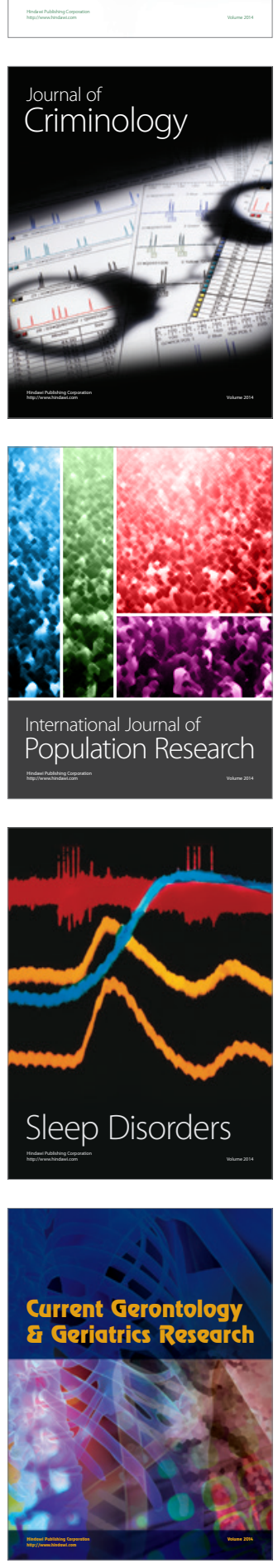
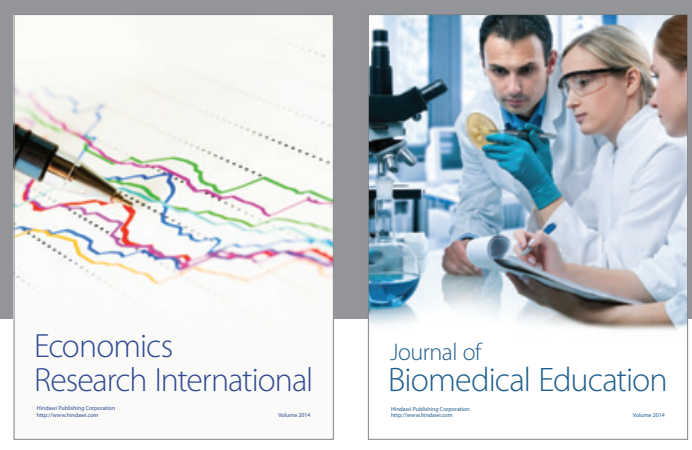

Journal of

Biomedical Education

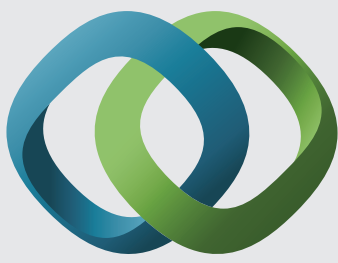

\section{Hindawi}

Submit your manuscripts at

http://www.hindawi.com
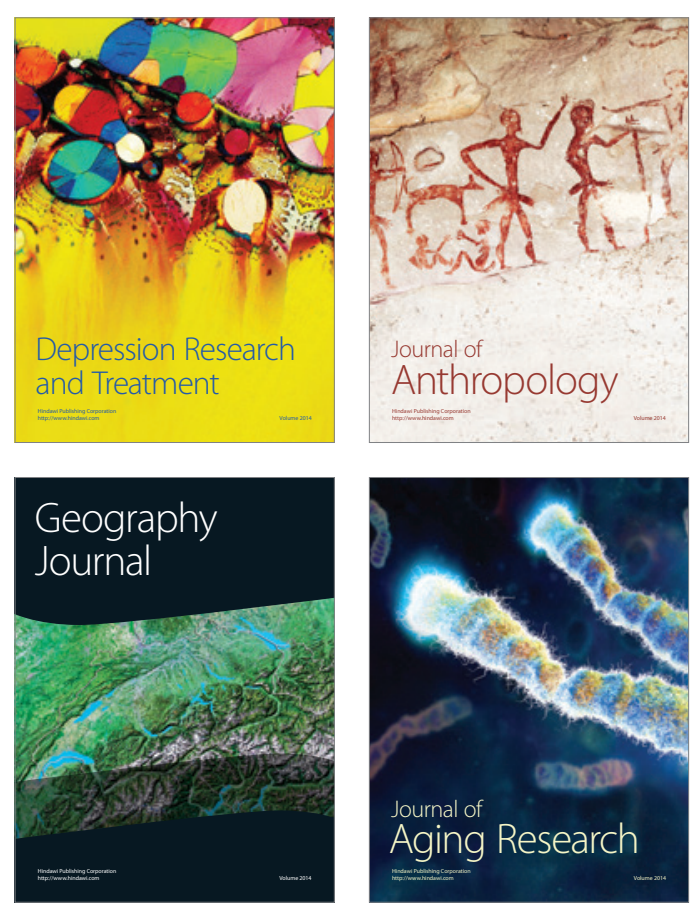

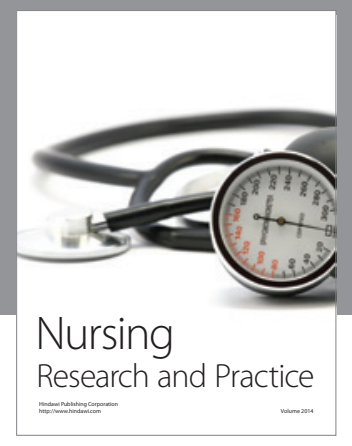

Nursing

Research and Practice

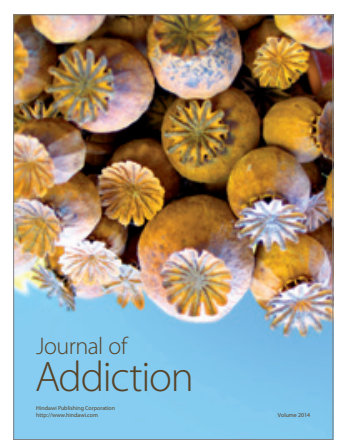

Child Development

Research

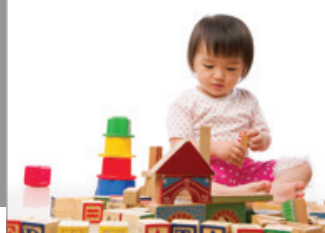

迥
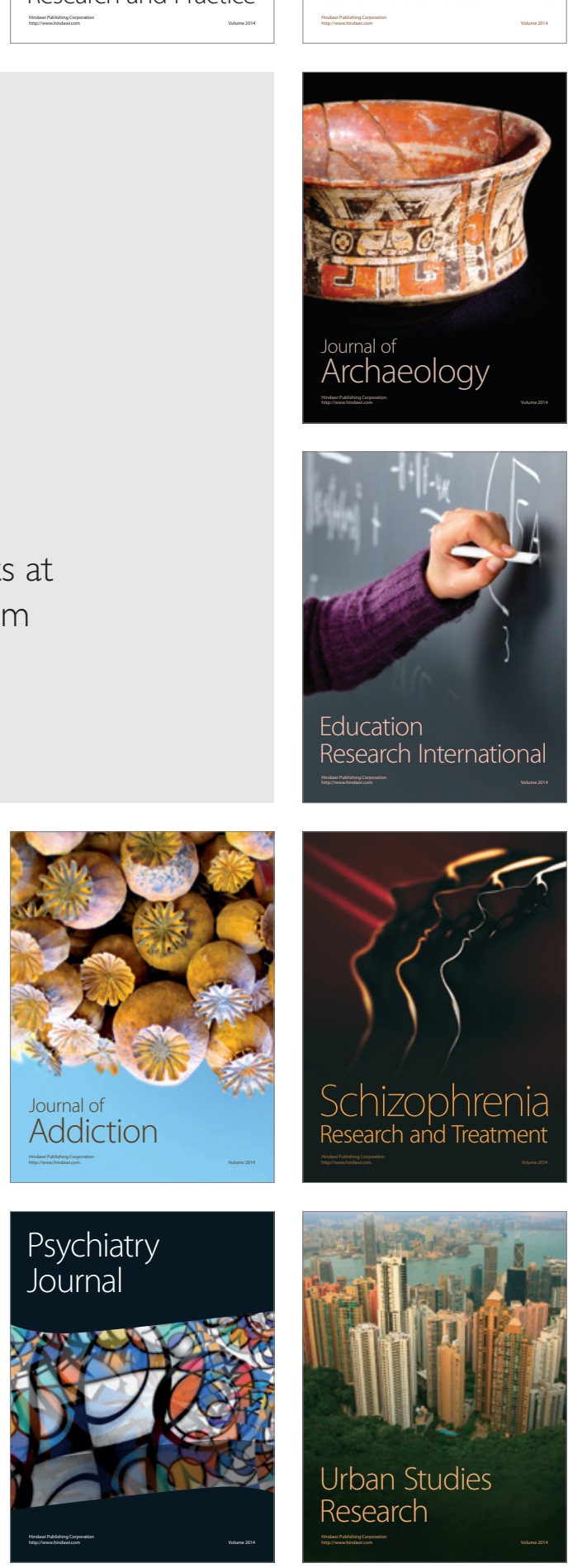